\title{
Effects on density, shrinking, color changing and chemical surface analysis through FTIR of Tectona grandis thermo-treated
}

\author{
Density, shrinking, color changing and chemical \\ analysis by FTIR of the thermally-treated teak wood
}

\author{
Luis Diego Méndez-Mejías ${ }^{1}$ e Roger Moya ${ }^{1}$
}

\begin{abstract}
Resumo
O tratamento térmico da madeira tem sido implementado, nos últimos anos, como uma opção para melhorar a sua durabilidade. Este estudo avaliou o efeito da temperatura do tratamento térmico na densidade, contração, alteração da cor (sistema $L^{*} a^{*} b^{*}$ ) e composição química aplicando o FTIR na madeira de Tectona grandis. Amostras de madeira de cerne e de alburno com padrões de corte radial e tangencial foram expostas a três níveis de temperatura, $210^{\circ} \mathrm{C}, 215^{\circ} \mathrm{C}$ e $220^{\circ} \mathrm{C}$, durante 6 horas e as propriedades das madeiras tratadas foram comparadas com a madeira não tratada. Os resultados indicaram que a densidade da madeira decresceu de 0,61 para $0,49 \mathrm{~g} \mathrm{~cm}^{-3}$, com uma tendência a diminuição com o aumento da temperatura. A contração da madeira variou de 2,61 a 1,58 \% não sendo encontradas diferenças estatísticas entre as temperaturas. As análises do FTIR mostraram um leve aumento nas bandas de 1024, 1098 , 1131, 1249, 2928 e $3340 \mathrm{~cm}^{-1}$, indicando uma alteração da lignina com o aumento da temperatura usada no tratamento térmico. A alteração da cor da madeira foi maior na luminosidade $\left(L^{*}\right)$ seguido pelo seu avermelhamento $\left(a^{*}\right)$. A tonalidade amarela $\left(b^{*}\right)$ mostrou as menores alterações. Finalmente, o tratamento térmico a temperatura de $220^{\circ} \mathrm{C}$ mostrou os melhores resultados em relação às propriedades da madeira avaliadas.
\end{abstract}

Palavras-chave: Tratamento térmico, madeira tropical, temperatura, estrutura da madeira, grupos funcionais, polímeros.

\begin{abstract}
Thermal-treatment wood is used as an option to improve durability of wood in recent years. This study evaluated the effect of temperature in thermally treated Tectona grandis wood in density, shrinking, color changing $\left(\mathrm{L}^{*} \mathrm{a}^{*} \mathrm{~b}^{*}\right.$ system) and surface analysis through FTIR. Sapwood and heartwood boards sawn with radial and tangential patterns were exposed to three temperature-levels: $210^{\circ} \mathrm{C}, 215^{\circ} \mathrm{C}, 220^{\circ} \mathrm{C}$ during 6 hours and thermally treated wood properties were compared with untreated wood. Results showed that density decreased from 0.61 to $0.49 \mathrm{~g} \mathrm{~cm}^{-3}$ with a tendency to decrease as temperature increases. Wood shrinking ranges from 2.61 to $1.58 \%$ and no statistical differences between temperatures were found. The FTIR analysis showed a slight increase in the bands at $1024 \mathrm{~cm}^{-1}, 1098 \mathrm{~cm}^{-1}, 1131 \mathrm{~cm}^{-1}, 1249 \mathrm{~cm}^{-1} 2928$ $\mathrm{cm}^{-1}$ and $3340 \mathrm{~cm}^{-1}$ with the temperature increases, indicating a lignin change. Color change showed major changes in luminosity $\left(L^{*}\right)$, followed by redness $\left(a^{*}\right)$; while yellowness $\left(b^{*}\right)$ showed minor changes. Finally, the thermal treatment at $220^{\circ} \mathrm{C}$ had the best results regarding the evaluated properties.
\end{abstract}

Keywords: Heat-treatment, tropical wood, temperature, wood structure, functional groups, polymers.

\section{INTRODUCTION}

Wood is susceptible to dimensional changes due to the change in environmental conditions, which greatly limits its use in some applications (KOCAEFE et al., 2015). Nevertheless, these weaknesses can be improved through technical and engineering methods, where structural properties or durability were improved (PRIADI; HIZIROGLU, 2013).

Durability improved using chemical substances as wood preservatives or through nanotechnology (MOYA et al., 2014a). Use of these products becomes increasingly limited, calling for the need of research on new techniques to increase durability in wood with low toxicity methods or eliminating the use of chemicals (TREVISAN et al., 2014).

A technique to increase durability is thermal treatment. This process involves exposing wood to high temperatures (from $170{ }^{\circ} \mathrm{C}$ at $220^{\circ} \mathrm{C}$ ), in the absence of atmospheric oxygen, which leads

\footnotetext{
${ }^{1} \mathrm{MsC}$ in Forest Science. Instituto Tecnológico de Costa Rica / Escuela de Ingeniería Forestal. P.O. Box: 159-7050. Cartago, Costa Rica. E-mail: ldiegomm@gmail.com.
} 
to changes in its structure and chemical composition: it can improve dimensional stability of wood; increase resistance to several biologic agents and produce an increasing of color uniformity (ZIGON et al., 2015). Temperature and time used with thermal-treatment varies with species, wood dimensions, moisture content and final use of wood (KESIK et al., 2014).

Teak (Tectona grandis) is one of the most important tropical species due to its properties and versatility of uses (TEWARI; MARISWAMY, 2013). Wood from fast-growing plantations has a higher juvenile wood content, which usually has low physical, mechanical and durability properties (MOYA et al., 2014b).

Some studies in teak wood have emphasized behavior, processes and characteristics of thermal treatment. For example, Lopes et al. $(2014 \mathrm{a}, \mathrm{b}, \mathrm{c})$ showed changes in some properties of juvenile wood (density, moisture content, color change, color uniformity, and resistance to weathering) for thermo-treated teak wood in Brazil at temperatures of $180^{\circ} \mathrm{C}$ and $200{ }^{\circ} \mathrm{C}$ during a time of 2 hours and 30 minutes. In another study carried out by KASHYAP et al. (2014), the effects of durability in laboratory conditions with white rot fungi of thermo-treated wood at three temperatures $\left(160^{\circ} \mathrm{C}\right.$, $180^{\circ} \mathrm{C}$ and $210^{\circ} \mathrm{C}$ ) during exposition times of $0.5,3,5$ and 25 hours were determined.

In spite of these studies, information about the process in thermally treated wood with industrial equipment is limited. In order to obtain an environmentally friendly product with better properties and characteristics enabling potential use and competition in the market this research was done. It aimed to determine the effect of three different temperature levels $\left(210^{\circ} \mathrm{C}, 215^{\circ} \mathrm{C}\right.$ and $\left.220^{\circ} \mathrm{C}\right)$ on thermally treated teak wood: in density, shrinking, color and surface analysis through Fourier Transform Infrared Spectroscopy (FTIR) with industrial equipment..

\section{MATERIALS AND METHODS}

\section{Origin and characteristics of the material used}

Wood used was wood from the second thinning from a Tectona grandis plantation, 11 years old, spacing of $3 \times 3 \mathrm{~m}$ (1100 trees ha-1). Density of the plantations was 475 trees ha ${ }^{-1}$, with an average diameter at breast height of $23 \mathrm{~cm}$ and total height of $14 \mathrm{~m}$. The plantation is located in the Northern Zone of Costa Rica and owned by the company Ethical Forestry S.A. 7-9 logs were felled from sample trees, logs were $1.25 \mathrm{~m}$ long. Logs were sawn into boards $7.5 \mathrm{~cm}$ wide x $2.5 \mathrm{~cm}$ thick x $1.25 \mathrm{~m}$ long and dried according to research conducted by Salas and Moya (2014).

\section{Sampling}

Thermal treatment was separate in sapwood and heartwood and within these types, wood with tangential and radial patterns. Then, 30 boards of about $7.5 \mathrm{~cm}$ wide $\times 2.5 \mathrm{~cm}$ thick $\mathrm{x} 1.25 \mathrm{~m}$ long were taken from each type of wood. Each of these samples was divided into 4 parts (boards of 7.5 $\mathrm{cm}$ wide $\times 2.5 \mathrm{~cm}$ thick $\times 30 \mathrm{~cm}$ long). Sapwood timber only had samples with tangential pattern, since it was not possible to get radial pattern.

\section{Thermal-treatment process}

Dried lumber, with approximately $12 \%$ moisture content was thermally treated in three different temperatures levels: $210^{\circ} \mathrm{C}, 215^{\circ} \mathrm{C}$ and $220^{\circ} \mathrm{C}$. For each treatment, 30 boards were selected per type of wood (sapwood and heartwood) and cutting section (tangential and radial). Each thermal treatment process was made independently and performed in the absence of oxygen. Boards were introduced and stacked into a thermowood pilot plant with the trade-name Valutec ${ }^{\circledR}$ (http://www. valutec.se). The thermal treatment process started with the drying for approximately 17 hours at a temperature starting from $130{ }^{\circ} \mathrm{C}$ to obtain $0 \%$ moisture content. Subsequently, temperature was increased from $130^{\circ} \mathrm{C}$ to the temperature defined for each type of thermal-treatment (210 ${ }^{\circ} \mathrm{C}, 215^{\circ} \mathrm{C}$ or $220^{\circ} \mathrm{C}$ ) and maintained during 6 hours. Next, a conditioning stage was applied during 7 hours; with steam, water and temperature applied to moisturize the timber and achieve approximately $6 \%$ moisture content. Finally, a cooling process was applied during 3 hours. The different treatments were defined as follows: untreated wood as control; thermal-treatments at 210 ${ }^{\circ} \mathrm{C} ; 215^{\circ} \mathrm{C}$ and $220^{\circ} \mathrm{C}$. 


\section{Determination of density and shrinking of wood}

Density of wood from each treatment was determined using samples $5 \mathrm{~cm}$ wide x $2.5 \mathrm{~cm}$ thick $\mathrm{x} 2.5 \mathrm{~cm}$ taken from each thermally treated board. Volume and weight were measured and density was determined (mass/volume). For the shrinking percentage of wood, 5 samples from the 30 samples of each treatment were selected. Width before and after thermo-treatment was measured and equation 1 was used for shrinkage determination:

$$
\text { Shrinking }(\%)=\left(\frac{\text { Dimension before }(\mathrm{mm})-\text { Dimension after }(\mathrm{mm})}{\text { Dimension before }(\mathrm{mm})}\right) \times 100
$$

\section{Measurement and analysis of FTIR spectra on wood surface}

For this analysis, 24 samples were prepared in total, 2 samples per type of thermal-treatment and per cutting section, with dimensions of $1.5 \mathrm{~cm}$ long $\mathrm{x} 1.5 \mathrm{~cm}$ wide and $0.4 \mathrm{~cm}$ thick, taken from the thermally treated boards. Subsequently, a Fourier Transformed Infrared Spectroscopy (FTIR) analysis was performed. Samples were measured on its surface with a Spectrometer Nicolet 380 FTIR (Thermo Scientific) using only a reflectance cell (equipped with a diamond crystal). All data were recorded at room temperature, in the spectral range of $4000-500 \mathrm{~cm}^{-1}$, by accumulating 32 scans with a resolution of $1 \mathrm{~cm}^{-1}$, with background correction every 10 minutes.

FTIR signals obtained from spectrum were subsequently processed with Microsoft Excel 2010 through scatter plots. An action range of 600 to $3600 \mathrm{~cm}^{-1}$ was defined to identify vibration of the bands and the main components in each of the samples tested, based on previous studies where action range for the different functional groups are defined (BERROCAL et al., 2016).

\section{Color changes in wood}

Color on wood surface was measured using the color system Lab. For measuring color, a spectrophotometer miniSkan XE Plus from HunterLab was used, with standardized chromatologic system CIE L*a*b. Measurement ranged from 400 to $700 \mathrm{~nm}$, with an opening in the measuring point of $11 \mathrm{~mm}$. Observing reflection includes the specular component (SCI mode), with a $10^{\circ}$ angle, which is normal to the specimen surface (D65/10); a view field of $2^{\circ}$ (Standard observer, CIE 1931 ) and an illumination level D65 (corresponding to Daylight in $6500 \mathrm{~K}$ ). Color system CIELAB enables color measurement three-dimensionally.

Color was measured before and after the thermal treatment and then the total color change was quantified $\left(\Delta \mathrm{E}^{*}\right)$, according the standard ASTM D 2244 (ASTM, 2005) through equation 2:

$$
\Delta \mathrm{E} *=\sqrt{(\Delta \mathrm{L} *)^{2}+(\Delta \mathrm{a} *)^{2}+(\Delta \mathrm{b} *)^{2}}
$$

Where: $\Delta \mathrm{L}^{*}=\mathrm{L}^{*}{ }_{\text {after thermal-treatment }}-\mathrm{L}^{*}$ before thermal-treatment,$\Delta \mathrm{a}^{*}=\mathrm{a}^{*}{ }_{\text {after thermal-treatment }}-\mathrm{a}^{*}{ }_{\text {before thermal-treatment }}$ and $\Delta \mathrm{b}^{*}=\mathrm{b}^{*}{ }_{\text {after thermal-treatment }}-\mathrm{b}^{*}$ before thermal-treatment

\section{Selection of the best treatment}

To select the treatment with the most favorable results with the least density variation, the least shrinking and the major color change, each variable was weighted with a score to calculate and index later. Weighting each variable evaluated was established according to data variation, considering those that bring a major change and thus are of greater importance as selection criteria. For density and shrinking, a contribution of $30 \%$ was defined for each and color change represents $40 \%$ on the selection of the treatment with the most desired results (Table 1). Categorizations defined for variables of density, shrinking and total color change can be seen in Table 1:

Table 1. Classification parameters for density, shrinking percentage and color change for thermally treated teak wood.

Tabela 1. Parâmetros de classificação para a densidade, porcentagem de contração e alteração de cor da madeira de teca tratada termicamente.

\begin{tabular}{lccc}
\hline Density $\left(\mathbf{g ~ c m}^{-3}\right)$ & Shrinking $(\%)$ & $\Delta \mathbf{E}^{*}$ & Classification \\
\hline$<0.51$ & $>2.35$ & $<26.66$ & Bad (1 pt) \\
$0.51-0.53$ & $1.84-2.35$ & $26.66-36.17$ & Regular (2 pts) \\
$>0.53$ & $<1.84$ & $>36.17$ & Good (3 pts) \\
\hline
\end{tabular}


Moya e Méndez-Meija - Effects on density, shrinking, color changing and

chemical surface analysis through FTIR of Tectona grandis thermo-treated

\section{Statistic analysis}

A variance analysis (ANOVA) was applied to estimate data variation, where the assumptions of normality and homoscedasticity were verified. For color change data, parameters $L^{*}, a^{*}, b^{*}$ were transformed at $\log _{10}$ to meet the assumptions. The existence of significant difference between treatments was verified through Tukey's Test $(\mathrm{P}<0.05)$. For FTIR spectra, a scatter plot of frequency values $\mathrm{cm}^{-1}$ of the bands (X axis) and absorbance (Y axis) was used, to try observing changes in the bands of the different functional groups.

\section{RESULTS AND DISCUSSION}

\section{Density and shrinking of the wood}

Variation of density and shrinking of different types of thermally treated wood (sapwood or heartwood) and cutting section (radial or tangential) is shown in Table 2. A slight decrease in wood density is observed when thermo-treatment temperature increases in the types of wood and cutting sections, however it fails to be statistically different; but there is a statistical difference with untreated wood or control (Table 2). Shrinking percentages obtained for samples from the different treatments tend to be more variable; however, it was not possible to establish statistical differences between temperature effects.

Table 2. Density and shrinking percentage of the thermally treated teak wood at three different temperature levels according to wood type and cutting section.

Tabela 2. Densidade e porcentagem de contração da madeira de teca tratada termicamente sob diferentes níveis de temperatura de acordo com o tipo de madeira e plano de corte.

\begin{tabular}{|c|c|c|c|c|}
\hline Wood type & Cutting section & Treatment & Shrinking (\%) & Density $\left(\mathrm{g} \mathrm{cm}^{-3}\right)$ \\
\hline \multirow{4}{*}{ Sapwood } & \multirow{4}{*}{ Tangential } & Control & ----------- & $0.60( \pm 0.05) \mathrm{B}$ \\
\hline & & $210^{\circ} \mathrm{C}$ & $1.75( \pm 0.64) \mathrm{A}^{*}$ & $0.54( \pm 0.04) \mathrm{A}$ \\
\hline & & $215^{\circ} \mathrm{C}$ & $1.58( \pm 0.80) \mathrm{A}$ & $0.53( \pm 0.04) \mathrm{A}$ \\
\hline & & $220^{\circ} \mathrm{C}$ & $2.07( \pm 0.57) \mathrm{A}$ & $0.53( \pm 0.04) \mathrm{A}$ \\
\hline \multirow{8}{*}{ Heartwood } & \multirow{4}{*}{ Radial } & Control & ----------- & $0.56( \pm 0.06) \mathrm{B}$ \\
\hline & & $210^{\circ} \mathrm{C}$ & $2.09( \pm 1.12) \mathrm{A}$ & $0.52( \pm 0.05) \mathrm{A}$ \\
\hline & & $215^{\circ} \mathrm{C}$ & $2.24( \pm 0.42) \mathrm{A}$ & $0.49( \pm 0.04) \mathrm{A}$ \\
\hline & & $220^{\circ} \mathrm{C}$ & $1.90( \pm 0.54) \mathrm{A}$ & $0.50( \pm 0.05) \mathrm{A}$ \\
\hline & \multirow{4}{*}{ Tangential } & Control & ----------- & $0.61( \pm 0.06) \mathrm{B}$ \\
\hline & & $210^{\circ} \mathrm{C}$ & $2.16( \pm 0.94) \mathrm{A}$ & $0.55( \pm 0.05) \mathrm{A}$ \\
\hline & & $215^{\circ} \mathrm{C}$ & $1.94( \pm 1.66) \mathrm{A}$ & $0.54( \pm 0.05) \mathrm{A}$ \\
\hline & & $220^{\circ} \mathrm{C}$ & $2.61( \pm 0.79) \mathrm{B}$ & $0.55( \pm 0.05) \mathrm{A}$ \\
\hline
\end{tabular}

*Value in parentheses indicates standard deviation and values with similar letters indicate no statistically significant difference between treatments for $95 \%$ confidence.

Decreasing wood density according to the different thermal-treatment temperatures (Table 2) occurred due to degradation of wood components during the roasting process, specifically removing volatile contents (extractives, low molecular weight components) through chemical reactions occurring during the process (KOCAEFE et al., 2008).

Nevertheless, no significant differences were found between the different temperatures (Table 2), coinciding with the results by Kasemsiri et al. (2012) and Guller (2012) in Juniperus virginiana and Pinus nigra species, respectively. This lack of difference can be explained as indicated by Uribe and Ayala (2015), who mention that although there is variation by weight loss and decrease in the volume of the samples after applying the thermal treatment process, is not significant enough to cause a noticeable change between the different treatments. Besides, before $170{ }^{\circ} \mathrm{C}$ most components are eliminated (KOCAEFE et al., 2008), temperature that reaches biomass in any of the different thermal-treatment temperatures.

For the shrinking percentage in wood at different thermal treatment temperatures (Table 2), although no significant differences were found regardless the type of wood or cutting section, wood with tangential pattern had greater shrinking than radial cut for treatment at $220^{\circ} \mathrm{C}$. This difference appears due to tangential direction, which has greater dimensions instability due to vertical orientation of micro-fibrils in the S2 layer on the cell wall and the orientation of parenchyma cells in radial direction, (PRIADI; HIZIROGLU, 2013). However, such behavior is not met at the other 
temperatures, since tangential pattern in sapwood and heartwood showed lower shrinking values compared to values obtained in radial pattern wood (Table 2).

\section{Analysis of FTIR spectra on the surface of wood}

The FTIR spectra of the untreated and thermally treated teak wood are presented in figure 1 . This shows that the greatest effects stem from the different functional groups in wood components in the range of $1800-800 \mathrm{~cm}^{-1}$. From range $1800 \mathrm{~cm}^{-1}$ onwards, very little variation is observed, except for the bands between 3600 to $2750 \mathrm{~cm}^{-1}$ assigned to the stretching of hydroxyl groups (Figure 1).

In Figure 1a it can be observed that for sapwood timber with tangential pattern, bands for control and $220^{\circ} \mathrm{C}$ treatments have similar behavior, but with a decrease in the different signals obtained compared to treatments at $210{ }^{\circ} \mathrm{C}$ and $215{ }^{\circ} \mathrm{C}$, where $215^{\circ} \mathrm{C}$ has the highest increase peak in the bands $1024 \mathrm{~cm}^{-1}, 1098 \mathrm{~cm}^{-1}, 1131 \mathrm{~cm}^{-1}, 1249 \mathrm{~cm}^{-1}, 1311 \mathrm{~cm}^{-1}, 1361 \mathrm{~cm}^{-1}, 2928 \mathrm{~cm}^{-1}$ and $3340 \mathrm{~cm}^{-1}$, but with little difference regarding treatment at $210^{\circ} \mathrm{C}$. Then the great signal of FTIR were reflected in $1024 \mathrm{~cm}^{-1}, 1098 \mathrm{~cm}^{-1}, 1131 \mathrm{~cm}^{-1}, 1249 \mathrm{~cm}^{-1}, 1311 \mathrm{~cm}^{-1}, 1361 \mathrm{~cm}^{-1}, 2928 \mathrm{~cm}^{-1}$ and $3340 \mathrm{~cm}^{-1}$ for thermally-treated teak with temperatures from 210 to $220^{\circ} \mathrm{C}$.

Signals obtained for heartwood with tangential pattern by the different treatments (Figure 1b) show that treatments at $210{ }^{\circ} \mathrm{C}$ and $215^{\circ} \mathrm{C}$ have a similar behavior with each other with a decrease in band intensity, compared to treatments at $220^{\circ} \mathrm{C}$ and control that represent peaks with greater increase. Additionally, an increase in the bands at $1024 \mathrm{~cm}^{-1}, 1098 \mathrm{~cm}^{-1}, 1131 \mathrm{~cm}^{-1}, 1249 \mathrm{~cm}^{-1} 2928$ $\mathrm{cm}^{-1}$ and $3340 \mathrm{~cm}^{-1}$ can be appreciated as thermal treatment temperature rises.

As for heartwood with radial pattern (Figure 1c), it was found that treatments at $210{ }^{\circ} \mathrm{C}, 220$ ${ }^{\circ} \mathrm{C}$ and control have signals with similar magnitudes, while among them, $220{ }^{\circ} \mathrm{C}$ has the highest magnitude. Signals obtained for treatment at $215{ }^{\circ} \mathrm{C}$ have a decrease in all the signals compared to the other treatments.

Increase in the intensity of bands at $1508 \mathrm{~cm}^{-1}$ and $1428 \mathrm{~cm}^{-1}$ (Figure 1), assigned to the carboxyl group which may be due to stretching of aromatic skeleton components of lignin and band at 1740 $\mathrm{cm}^{-1}$, assigned to the stretching vibration of carbonyl, carboxyl and acetyl groups (CHEN et al., 2014; LI et al., 2015). Therefore, there is a change in the chemical structure of lignin in wood that has been thermo-treated.

Changes obtained in the intensity of bands at $1131 \mathrm{~cm}^{-1}, 1098 \mathrm{~cm}^{-1}, 1024 \mathrm{~cm}^{-1}$, and $669 \mathrm{~cm}^{-1}$, may be related to the modification of cellulose and hemicellulose (YILDIZ et al., 2013). According to Lionetto et al. (2012), changes in bands at $1318 \mathrm{~cm}^{-1}$ and $1053 \mathrm{~cm}^{-1}$ are associated to increases in the stretching vibrations in glucose rings, which may be due to cleavage and dehydration of amorphous carbon hydrates or crystallization of the para-crystalline region of cellulose, so signals obtained in bands at $1311 \mathrm{~cm}^{-1}$ may be due to these changes. Signals obtained in $1024 \mathrm{~cm}^{-1}$ are assigned to stretching variation of $\mathrm{C}=\mathrm{O}$ (LIONETTO et al., 2012).

In band at $1589 \mathrm{~cm}^{-1}$ a stretching of the aromatic rings of lignin can be detected (FACKLER et al., 2011). Signals obtained at $1311 \mathrm{~cm}^{-1}$ are assigned to $\mathrm{C}=\mathrm{O}$ vibration in lignin and at $1361 \mathrm{~cm}^{-1}$ associated to deformation of $\mathrm{C}-\mathrm{H}$ group in cellulose and hemicellulose. Moreover, Kocaefe et al. (2008) indicate that bands at $1260 \mathrm{~cm}^{-1}$ are due to cleavage of acetyl groups in hemicellulose, which form carboxylic acids and lignin degradation; in this case signals obtained in bands at $1249 \mathrm{~cm}^{-1}$ may be associated to these factors (Figure 1).

Signals obtained between $2928 \mathrm{~cm}^{-1}$ and $3340 \mathrm{~cm}^{-1}$ correspond to functional groups of hydroxyl, coinciding with that reported by Li et al. (2015) and Huang et al. (2012) who indicated that bands between the range 3800-2750 $\mathrm{cm}^{-1}$ are assigned to hydroxyl and methyl groups or stretching vibrations of methylene, in the components of hemicellulose, lignin and cellulose.

Otherwise, Yildiz et al. (2013) indicated that thermal treatment causes a reduction of hydroxyl groups that are replaced by hydrophobic acetyl groups resulting from the reticulation between wood fibers by the thermal treatment applied. This thermal process is related to an increase in the dimensional stability of wood (KASEMSIRI et al., 2012; LEKOUNOUGOU; KOCAEFE, 2014). Besides, changes produced in the chemical structure of lignin, cellulose and hemicellulose caused by temperature, prevents reabsorption of water molecules linked together or with wood polymers improving the dimensional stability of the material (PRIADI; HIZIROGLU, 2013). 
a) Sapwood-Tangential

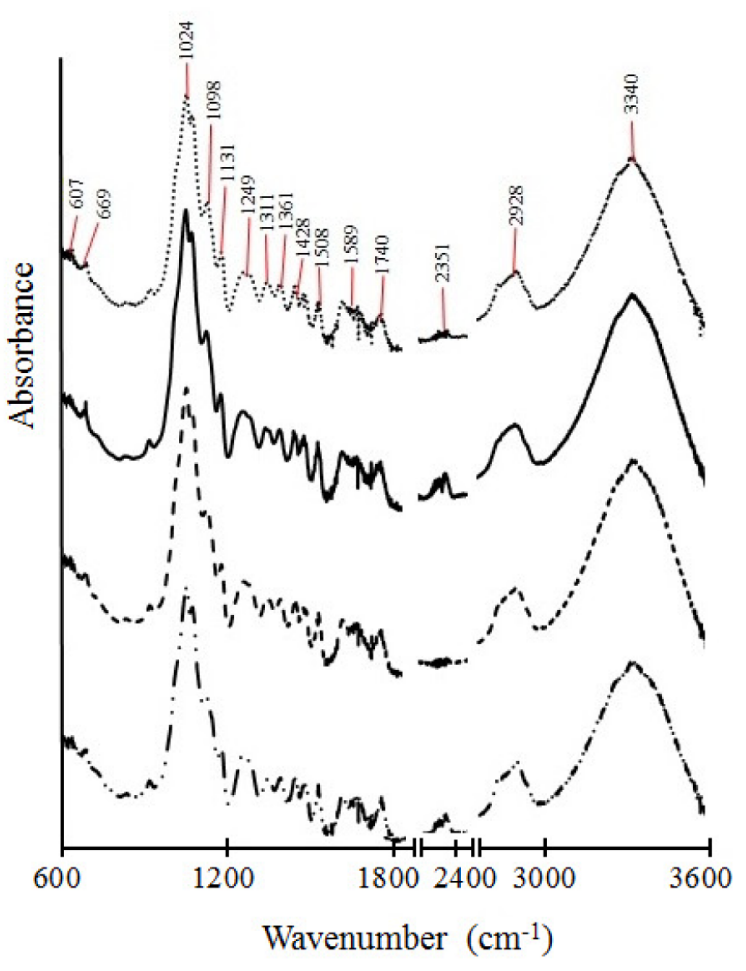

b) Heartwood-Tangential

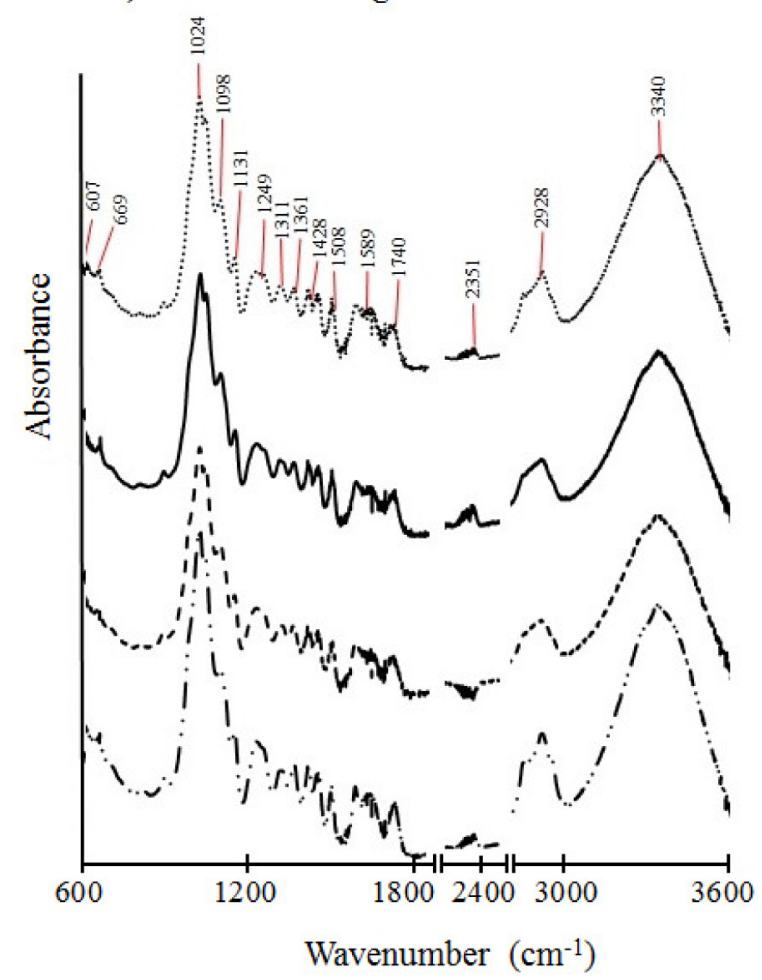

c) Heartwood-Radial

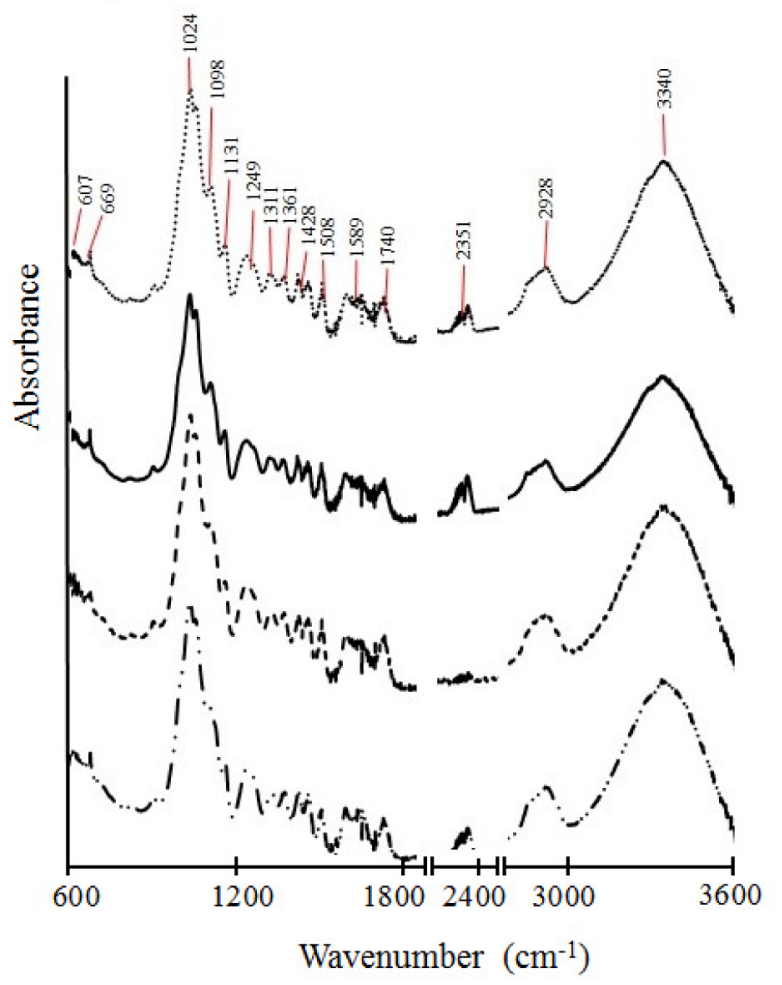

$-\cdots$ Control treatment --- Treatment at $210^{\circ} \mathrm{C}-$ Treatment at $215^{\circ} \mathrm{C} \cdots \cdots \cdots \cdot$ Treatment at $220^{\circ} \mathrm{C}$

Figure 1. FTIR representation of the untreated and thermally treated teak wood at three temperature levels, for sapwood in tangential section (a), heartwood in tangential section (b) and heartwood in radial section pattern (c).

Figura 1. Representação FTIR da madeira de teca não tratada e tratada termicamente a três níveis de temperatura, para alburno na seção tangencial (a), cerne na seção tangencial (b) e cerne na seção radial (c). 


\section{Color change in wood}

Color parameters of the surface of thermally treated teak wood is presented in Table 3. A growth trend can be appreciated in the total color change $\left(\Delta \mathrm{E}^{*}\right)$ as the temperature of each thermal treatment process rises, where the samples of sapwood with tangential pattern changed the highest total color changes. Also, $\Delta \mathrm{E}^{*}$ is greater in wood with radial pattern than in wood with tangential pattern in the different temperatures. Color changes are shown visually in figure 2, where it is observed that when temperature increases, teak wood tends to darken and wood color presented a tendency to color uniformity. Regarding the different parameters composing color, it was observed that $\Delta \mathrm{L}^{*}$ and $\Delta \mathrm{b}^{*}$ follow a trend of increase in negative, the higher the treatment temperature is; whereas values for $\Delta \mathrm{a}^{*}$ had a different trend increasing from treatment at $210^{\circ} \mathrm{C}$ to $215^{\circ} \mathrm{C}$ and later with a decrease at $220{ }^{\circ} \mathrm{C}$.

Table 3. Color change parameters $\left(\Delta \mathrm{L}^{*}, \Delta \mathrm{a}^{*}, \Delta \mathrm{b}^{*}\right)$ and total color change $\left(\Delta \mathrm{E}^{*}\right)$ of the thermally treated teak wood at three different temperatures according to wood type and cutting section.

Tabela 3. Parâmetros de alteração da color $\left(\Delta \mathrm{L}^{*}, \Delta \mathrm{a} *, \Delta \mathrm{b}^{*}\right)$ e alteração total da cor $\left(\Delta \mathrm{E}^{*}\right)$ da madeira de teca tratada termicamente sob três diferentes temperaturas de acordo com o tipo de madeira e plano de corte.

\begin{tabular}{|c|c|c|c|c|c|c|}
\hline \multirow{2}{*}{ Wood type } & \multirow{2}{*}{$\begin{array}{l}\text { Cutting } \\
\text { section }\end{array}$} & \multirow{2}{*}{ Treatment } & \multicolumn{4}{|c|}{ Color parameters } \\
\hline & & & $\Delta \mathbf{L}^{*}$ & $\Delta \mathbf{a}^{*}$ & $\Delta \mathbf{b}^{*}$ & $\Delta \mathbf{E}^{*}$ \\
\hline \multirow{3}{*}{ Sapwood } & \multirow{3}{*}{ Tangential } & $210^{\circ} \mathrm{C}$ & $-33.0( \pm 3.3) A^{*}$ & $5.3( \pm 1.2) \mathrm{A}$ & $-3.3( \pm 3.6) \mathrm{A}$ & $33.8( \pm 3.4) \mathrm{A}$ \\
\hline & & $215^{\circ} \mathrm{C}$ & $-35.3( \pm 3.2) \mathrm{B}$ & $5.3( \pm 1.5) A$ & $-3.6( \pm 3.9) \mathrm{AB}$ & $36.1( \pm 3.3) \mathrm{B}$ \\
\hline & & $220^{\circ} \mathrm{C}$ & $-40.0( \pm 7.8) \mathrm{B}$ & $3.9( \pm 1.2) \mathrm{A}$ & $-6.7( \pm 4.2) \mathrm{B}$ & $40.9( \pm 7.8) \mathrm{B}$ \\
\hline \multirow{6}{*}{ Heartwood } & \multirow{3}{*}{ Radial } & $210^{\circ} \mathrm{C}$ & $-21.4( \pm 3.0) \mathrm{A}$ & $0.9( \pm 1.9) \mathrm{A}$ & $-6.4( \pm 3.3) \mathrm{A}$ & $22.7( \pm 3.1) \mathrm{A}$ \\
\hline & & $215^{\circ} \mathrm{C}$ & $-26.0( \pm 3.2) \mathrm{B}$ & $1.1( \pm 1.5) \mathrm{A}$ & $-9.0( \pm 3.0) A B$ & $27.6( \pm 3.5) \mathrm{B}$ \\
\hline & & $220^{\circ} \mathrm{C}$ & $-26.4( \pm 5.1) \mathrm{B}$ & $-0.7( \pm 1.7) \mathrm{A}$ & $-11.8( \pm 3.0) \mathrm{B}$ & $29.2( \pm 5.1) \mathrm{B}$ \\
\hline & \multirow{3}{*}{ Tangential } & $210^{\circ} \mathrm{C}$ & $-19.5( \pm 4.3) \mathrm{A}$ & $1.1( \pm 2.4) \mathrm{A}$ & $-7.3( \pm 7.0) \mathrm{A}$ & $21.9( \pm 5.2) \mathrm{A}$ \\
\hline & & $215^{\circ} \mathrm{C}$ & $-21.8( \pm 3.1) \mathrm{B}$ & $1.2( \pm 2.9) \mathrm{A}$ & $-9.7( \pm 4.1) \mathrm{AB}$ & $24.3( \pm 3.4) \mathrm{B}$ \\
\hline & & $220^{\circ} \mathrm{C}$ & $-24.9( \pm 3.6) \mathrm{B}$ & $-0.7( \pm 2.7) \mathrm{A}$ & $-9.0( \pm 4.7) \mathrm{B}$ & $26.9( \pm 4.2) \mathrm{B}$ \\
\hline
\end{tabular}

* Value in parentheses indicates standard deviation and values with similar letters indicate no statistically significant difference between treatments for $95 \%$ confidence.

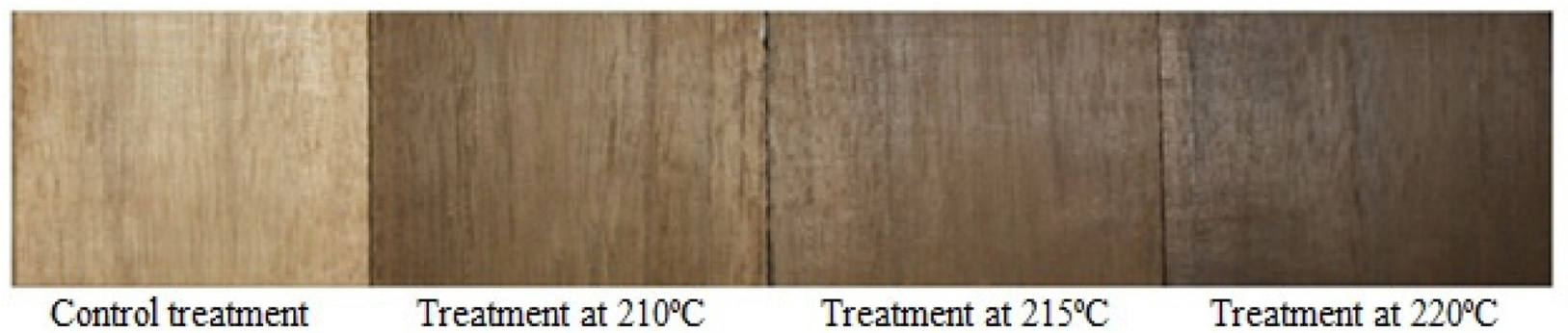

Control treatment

Treatment at $210^{\circ} \mathrm{C}$

Treatment at $215^{\circ} \mathrm{C}$

Treatment at $220^{\circ} \mathrm{C}$

Figure 2. Color changes in the thermally-treated teak wood, at three different temperatures.

Figura 2. Alteração da cor da madeira de teca tratada termicamente sob três diferentes temperaturas.

Values obtained for parameter $\Delta \mathrm{L}^{*}$ were entirely negative (Table 3 ), which reduces the clarity of the thermally treated wood, situation that is visually checked with color change (Figure 2). In this case, values obtained indicate that there was a darkening of wood. However, decreasing of clarity occurs more in sapwood than in heartwood timber. Within this heartwood type, major change happens in the radial pattern and minor change in the tangential pattern (Figure 2).

Meanwhile, parameter $\Delta \mathrm{a}^{*}$ was not affected statistically by the treatment applied (Table 3 ), indicating that temperature applied to wood achieves a small variation of redness, but, color change in this hue is not significant. Variation occurred with a small increase in this parameter value after thermal treatment; showing an increase in the reddish hue of thermal-treated wood. The only exception occurred in heartwood with radial and tangential pattern for treatment at $220^{\circ} \mathrm{C}$ that showed a trend to get a more greenish color (diminished value of $\mathrm{a}^{*}$ ).

Also, a slight increase occurred in parameter $\Delta b^{*}$ as temperature increases (Table 3 ), indicating a decrease in the yellow hue of wood, where the major change happens when temperature increases in sapwood with tangential pattern.

Finally, it was found that at higher temperature there is more color change $\left(\Delta \mathrm{E}^{*}\right)$ regardless of the type of wood or cutting section (Table 3). However, samples of heartwood have higher values of 
$\Delta \mathrm{E}^{*}$. This behavior occurs due to the emergence of several chemical changes in wood when thermaltreatment is applied (CHEN et al., 2014). During thermal-treatment process, some components of wood are degraded or modified through reactions such as dehydration, hydrolysis, oxidation, decarboxylation and trans-glycosylation (KOCAEFE et al., 2008), which are more noticeable in sapwood that generally has a clearer tonality.

Presence of functional groups as carbonyl, quinoid structures, structures of lignin or hemicellulose, may play an important role forming colored substances during thermal treatment (YILDIZ et al., 2013), which can be seen in the signals obtained in bands at $1508 \mathrm{~cm}^{-1}, 1428 \mathrm{~cm}^{-1}$ and $1740 \mathrm{~cm}^{-1}$ (Figure 2) associated to carbonyl groups. Because of this, it is reasonable to assume the existence of chemical changes in lignin and hemicellulose produced by exposing the material to heat. Heat causes a change of color on the surface of wood due to residual extractives (CHEN et al., 2014). These chemical changes may be due to modification of lignin and hemicellulose in the structure of wood that correspond to the signals obtained in bands at $1131 \mathrm{~cm}^{-1}, 1098 \mathrm{~cm}^{-1}, 1024 \mathrm{~cm}^{-1}, 669$ $\mathrm{cm}^{-1}$, and $1260 \mathrm{~cm}^{-1}$ (Figure 2) causing color changes in wood. Thermal-treated wood produces, as consequence, degradation of lignin and hemicellulose and a darkening in the color of wood, which is greater as temperature increases (HUANG et al., 2012).

\section{Selecting the best treatment}

Input percentage for the variables of shrinking and density tend to remain and decrease as thermal treatment temperature rises. For $\Delta \mathrm{E}^{*}$ of the samples, an increasing trend is observed as thermal treatment temperature increases (Table 4). Regarding total contribution of the variables together, treatment at $220^{\circ} \mathrm{C}$ yielded the highest percentage with the greatest percentage amount; however, samples subjected to this treatment showed greater shrinking and lower density represented with lower percentage values (Table 4).

Table 4. Percentage contribution of density, shrinkage and total color change of the thermal treatment of teak wood at three different temperature levels on quality parameter of best temperature.

Tabela 4. Percentagem de contribuição de densidade, contração e alteração da cor de madeira termo-tratada de Tectona grandis em relação a diferentes níveis de temperatura no parâmetro a qualidade da melhor temperatura.

\begin{tabular}{lcccc}
\hline Treatment & Shrinking (\%) & Density (\%) & $\Delta \mathbf{E}^{*}(\%)$ & Total $(\%)$ \\
\hline $210^{\circ} \mathrm{C}$ & 11.05 & 12.00 & 10.00 & 33.05 \\
$215^{\circ} \mathrm{C}$ & 11.05 & 9.00 & 12.50 & 32.55 \\
$220^{\circ} \mathrm{C}$ & 7.89 & 9.00 & 17.50 & 34.39 \\
\hline
\end{tabular}

\section{CONCLUSIONS}

Results obtained for the evaluated parameters showed that thermal treatment using pilot plant (Valutec ${ }^{\circledR}$ ) at $220^{\circ} \mathrm{C}$ had better results than at 210 and $215^{\circ} \mathrm{C}$, reflecting the highest total percentage obtained from the selection variables defined. Although this is the treatment with highest color change percentage, it presents a higher shrinking and a lower density.

The evaluation of thermally treated wood properties showed that wood density decreased and total color change $\left(\Delta \mathrm{E}^{*}\right)$ increased with thermal treatment temperature increases; the greatest shrinking percentage was found in heartwood with tangential pattern and thermal-treated at 220 ${ }^{\circ} \mathrm{C}$. Finally, FTIR spectra showed that chemical modifications of lignin, cellulose and hemicelluloses are produced in thermal treatment of teakwood, especially with temperature increasing.

\section{ACKNOWLEDGMENTS}

We thank the Research and Extension Vice-rectory from Instituto Tecnológico de Costa Rica (ITCR) for funding this study and the company Ethical Forestry S.A. for providing the samples and some equipment needed to develop this study. 


\section{REFERENCES}

ASTM - AMERICAN SOCIETY FOR TESTING MATERIALS. D-2244-02: Standard practice for calculation of color tolerances and color differences from instrumentally measured color coordinates. Pennsylvania, 2005. 224 p.

BERROCAL, A.; MOYA, R.; RODRIGUEZ-SOLIS, M.; STARBIRD, R.; MUÑOZ, F. Surface chemical and colour characterization of juvenile Tectona grandis wood subjected to steam-drying treatments: effect of grain pattern and moisture content. Surface Review and Letters, Berlin, v. 23, n. 1, p. 1-14, 2016.

CHEN, Y.; TSHABALALA, M. A.; GAO, J.; STARK, N. M.; Fan, Y. Color and surface chemistry changes of extracted wood flour after heating at $120^{\circ}$ C. Wood Science and Technology, Berlin, v. 48, n. 1, p. 137-150, 2014.

FACKLER, K.; STEVANIC, J. S.; TERS, T.; HINTERSTOISSER, B.; SCHWANNINGER, M.; SALMÉN, L. FT-IR imaging microscopy to localize and characterize simultaneous and selective white-rot decay within spruce wood cells. Holzforschung, Berlin, v. 65, n. 3, p. 411-420, 2011.

GULLER, B. Effects of heat treatment on density, dimensional stability and color of Pinus nigra wood. African Journal of Biotechnology, v. 11, n. 9, p. 2204-2209, 2012.

HUANG, X.; KOCAEFE, D.; KOCAEFE, Y.; BOLUK, Y.; PICHETTE, A. A spectrocolorimetric and chemical study on color modification of heat-treated wood during artificial weathering. Applied Surface Science, v. 258, n. 14, p. 5360-5369, 2012.

KASEMSIRI, P.; HIZIROGLU, S.; RIMDUSIT, S. Characterization of heat treated Eastern red cedar (Juniperus virginiana L.). Journal of Materials Processing Technology, v. 212, n. 6, p. 1324-1330, 2012.

KASHYAP, A. K.; TRIPATHI, S.; PANT, H. Effect of heat treatment on decay resistance of Pinus Roxburghii wood against decaying fungi. Indian Forester, v. 140, n. 1, p. 65-69, 2014.

KESIK, H. I.; KORKUT, S.; HIZIROGLU, S.; SEVIK, H. An evaluation of properties of four heat treated wood species. Industrial Crops and Products, v. 60, p. 60-65, 2014.

KOCAEFE, D.; HUANG, X.; COCAEFE, Y. Dimensional stabilization of wood. Wood Structure and Function, v. 1, n. 3, p. 151-161, 2015.

KOCAEFE, D.; PONCSAK, S.; BOLUK, Y. Effect of thermal treatment on the chemical composition and mechanical properties of birch and aspen. BioResources, Raleigh, v. 3, n. 2, p. 517-537, 2008.

LEKOUNOUGOU, S.; KOCAEFE, D. Durability of thermally modified Pinus banksiana (Jack pine) wood against brown and white rot fungi. International Wood Products Journal, United Kingdom, v. 5, n. 2, p. 92-97, 2014.

LI, M. Y.; CHENG, S. C.; LI, D.; WANG, S. N.; HUANG, A. M.; SUN, S. Q. Structural characterization of steamheat treated Tectona grandis wood analyzed by FT-IR and 2D-IR correlation spectroscopy. Chinese Chemical Letters, v. 26, n. 2, p. 221-225, 2015.

LIONETTO, F.; DEL SOlE, R.; CANNOLETTA, D.; VASAPOLLO, G.; MAFFEZZOLI, A. Monitoring wood degradation during weathering by cellulose crystallinity. Materials, v. 5, n. 10, p. 1910-1922, 2012.

LOPES, J. D. O; GARCÍA, R. A.; NASCIMENTO, A. M.; LATORRACA, J. V. D. F. Color change of teak wood by heat treatment. Floresta e Ambiente, Seropédica, v. 21, n. 4, p. 521-534, $2014 \mathrm{a}$.

LOPES, J. D. O; GARCÍA, R. A.; NASCIMENTO, A. M.; LATORRACA, J. V. D. F. Color uniformization of the young teak wood by heat treatment. Revista Árvore, Viçosa, v. 38, n. 3, p. 561-568, 2014b.

Sci. For., Piracicaba, v. 44, n. 112, p. 811-820, dez. 2016

DOI: dx.doi.org/10.18671/scifor.v44n112.03 
Moya e Méndez-Meija - Effects on density, shrinking, color changing and

chemical surface analysis through FTIR of Tectona grandis thermo-treated

LOPES, J. D. O; GARCÍA, R. A.; NASCIMENTO, A. M.; LATORRACA, J. V. D. F. Physical properties of heattreated teak wood. Floresta e Ambiente, Seropédica, v. 21, n. 4, p. 569-577, $2014 \mathrm{c}$.

MOYA, R.; BERROCAL, A.; RODRIGUEZ-ZUÑIGA, A.; VEGA-BAUDRIT, J.; CHAVES-NOGUERA, S. Effect of silver nanoparticles on white-rot wood decay and some physical properties of three tropical wood species. Wood and Fiber Science, Madison, v. 46, n. 4, p. 527-538, 2014a.

MOYA, R.; BOND, B.; QUESADA, H. A review of heartwood properties of Tectona grandis trees from fastgrowth plantations. Wood Science and Technology, Verlag, v. 48, n. 2, p. 411-433, 2014b.

PRIADI, T;; HIZIROGLU, S. Characterization of heat treated wood species. Materials \& Design, v. 49, p. 575$582,2013$.

SALAS, C.; MOYA, R. KILN-, SOLAR-, AND AIR-DRYING BEHAVIOR OF LUMBER OF TECTONA GRANDIS AND GMELINA ARBOREA FROM FAST-GROWN PLANTATIONS: MOISTURE CONTENT, WOOD COLOR, AND DRYING DEFECTS. DRYING TECHNOLOGY: AN INTERNATIONAL JOURNAL, UNITED KINGDON, V. 32, N. 3, P. 301-310, 2014.

TEWARI, V. P.; MARISWAMY, K. M. HEARTWOOD, SAPWOOD AND BARK CONTENT OF TEAK TREES GROWN IN KARNATAKA, INDIA. JOURNAL OF FORESTRY RESEARCH, VERLAG, V. 24, N. 4, P. 721-725, 2013.

TREVISAN, H.; LATORRACA, J. V. F.; SANTOS, A. L. P.; TEIXEIRA, J. G.; CARVALHO, A. G. Analysis of rigidity loss and deterioration from exposure in a decay test field of thermorectificated Eucalyptus grandis wood. Wood Science and Technology, New York, v. 16, n. 2, p. 217-226, 2014.

URIBE, B. E. B.; AYALA, O. A. Characterization of three wood species (Oak, Teak and Chanul) before and after heat treatment. Journal of the Indian Academy of Wood Science, India, v. 12, n. 1, p. 54-62, 2015.

YILDIZ, S.; TOMAK, E. D.; YILDIZ, U. C.; USTAOMER, D. Effect of artificial weathering on the properties of heat treated wood. Polymer Degradation and Stability, v. 98, n. 8, p. 1419-1427, 2013.

ZIGON, J.; PIZZI, A.; ZHANG, H.; SEGA, B.; COP, M.; SERNEK, M. The influence of heat and chemical treatments of beech wood on the shear strength of welded and UF bonded specimens. European Journal of Wood and Wood Products, Berlin, v. 73, n. 5, p. 685-687, 2015.

Recebido em 29/09/2015

Aceito para publicação em 18/04/2016 